\title{
PENDEKATAN BALANCE SCORECARD UNTUK PENGUKURAN KINERJA PADA DINAS KESEHATAN KABUPATEN BONDOWOSO
}

\author{
Donie Setyawan \\ Fakultas Ekonomi dan Bisnis, Universitas Jember \\ dhoenkrek_84@yahoo.co.id
}

\begin{abstract}
Public sector performance of the government institutions in Bondowoso Regency is measured from organizational ability in realizing budget absorption at the end of the budget year. However, referring merely to the financial aspect cannot provide objective and comprehensive overview of the overall organizational performance. Therefore, an objective and comprehensive measurement is needed, both from the financial (quantitative) and non financial aspects (qualitative). This research aims to analyze the implementation of balanced scorecard concept in describing the overall performance achievement and determining organizational policies and strategies in the Health Department of Bondowoso Regency. This is a qualitative research applying case study approach. Data were collected from questionnaires distribution, interview, and literatures study. This research focuses on 4 perspectives in describing organizational service quality, i.e., financial perspective, customer perspective, internal business process perspective, and growth \& learning perspective. Results show that: (1) the financial performance quality is economically adequate, quite effective and efficient, (2) from the customer perspective, the performance quality is satisfactory, (3) the quality performance of internal business process is satisfactory, and (4) from the learning and growth perspective, the performance quality is satisfactory.
\end{abstract}

Keywords: Performance, Quality, Balanced Scorecard.

Abstrak: Kinerja sektor publik di instansi pemerintahan di Kabupaten Bondowoso diukur dari kemampuannya dalam merealisasikan penyerapan anggaran pada akhir tahun anggaran. Pengukuran aspek finansial dianggap tidak mampu memberikan gambaran yang objektif dan komprehensif terhadap kinerja organisasi secara keseluruhan sehingga dibutuhkan sebuah pengukuran kinerja yang dapat mengukur kinerja pemerintah secara keseluruhan untuk memberikan informasi yang cukup, baik dari aspek keuangan (kuantitatif) maupun non keuangan (kualitatif). Tujuan penelitian ini adalah untuk menganalisis penerapan konsep balanced scorecard pada Dinas Kesehatan Kabupaten Bondowoso dalam menggambarkan pencapaian kinerja secara keseluruhan dan menentukan kebijakan dan strategi. Penelitian ini merupakan penelitian deskriptif kualitatif dengan pendekatan studi kasus. Data dikumpulkan melalui kuesioner, wawancara, dan studi literatur. Pendekatan yang di gunakan untuk menggambarkan kualitas pelayanan difokuskan pada 4 perspektif yaitu: perspektif keuangan, perspektif pelanggan, perspektif proses bisnis internal, dan perspektif pertumbuhan \& pembelajaran. Hasil penelitian menunjukkan bahwa: (1) perspektif keuangan memiliki kualitas kinerja cukup ekonomis, cukup efektif dan efisien, (2) perspektif pelanggan memiliki kualitas kinerja memuaskan, (3) perspektif proses bisnis internal memiliki kualitas kinerja memuaskan, dan (4) perspektif pertumbuhan \& pembelajaran memiliki kualitas kinerja memuaskan.

Kata Kunci: Kinerja, Kualitas, Balanced Scorecard. 


\section{Pendahuluan}

Akuntabilitas kinerja sesuai yang diuraikan dalam Instruksi Presiden Nomor 7 Tahun 1999 adalah perwujudan kewajiban suatu instansi pemerintah untuk mempertanggung jawabkan keberhasilan/kegagalan pelaksanaan misi organisasi dalam mencapai tujuan dan sasaran yang telah ditetapkan melalui alat pertanggungjawaban secara periodik. Menurut Utomo (2001:3), fokus prioritas pelayanan publik adalah perencanaan pelayan publik yang akan diberikan sesuai kebutuhan dan keinginan masyarakat serta memperlakukan pengguna layanan sebagai customer sehingga berupaya memberikan pelayanan terbaik. Mutaqien (2006: 20-30) mengungkapkan bahwa kinerja organisasi adalah sebuah konsep yang menunjukkan gambaran keberhasilan organisasi dalam mencapai tujuan dan sasaran organisasi. Pengukuran kinerja bertujuan untuk memberikan arahan dalam penyusunan rencana kerja serta sebagai bahan evaluasi kerja yang telah dilakukan dalam mencapai sasaran organisasi.

Balanced Scorecard menjadi salah satu alat analisis yang dipergunakan untuk pengukuran kinerja organisasi yang memperluas perspektif atau pendekatan pada setiap unit organisasi yang saling berkaitan dalam melaksanakan strategi organisasi, dan tidak hanya melalui perspektif keuangan saja namun juga melalui perspektif pelanggan, perspektif bisnis internal dan perspektif pembelajaran dan pertumbuhan (Kaplan dan Norton, 2000: 18-30). Sharma (2009) menjelaskan bahwa balance scorecard merupakan alat manajemen strategis yang sangat penting yang dapat membantu organisasi, tidak hanya untuk mengukur kinerjanya namun juga untuk menentukan kebijakan atau strategi dalam pencapaian tujuan organisasinya.

Pengukuran kinerja pada Dinas Kesehatan Kabupaten Bondowoso selama ini melalui Laporan Akuntabilitas Kinerja Instansi Pemerintah (LAKIP) yang merupakan wujud akuntabilitas pencapaian kinerja instansi dalam pelaksanaan rencana strategis (Renstra) dan rencana kinerja yang telah ditetapkan melalui penetapan kinerja di awal tahun anggaran. Pengukuran kinerja yang dilakukan belum mencakup aspek non keuangan, sehingga diperlukan sebuah pengukuran kinerja untuk memberikan gambaran menyeluruh dengan mengakomodasi pengukuran kinerja dai berbagai aspek baik aspek keuangan maupun aspek non keuangan. Pemakaian konsep balanced scorecard diharapkan mampu memberikan gambaran yang lebih komprehensif terhadap pengukuran kinerja pada Dinas Kesehatan Kabupaten Bondowoso. 
Penggunaan balance scorecard untuk mengukur kinerja pada Dinas Kesehatan Kabupaten Bondowoso menggunakan empat perspektif seperti pada penelitian sebelumnya yaitu perspektif keuangan, perspektif pelanggan, perspektif proses bisnis internal dan perspektif pertumbuhan dan pembelajaran. Tujuan dari penelitian ini adalah untuk menganalisis penerapan konsep balanced scorecard pada Dinas Kesehatan Kabupaten Bondowoso untuk menunjukkan pencapaian kinerja secara keseluruhan dan menentukan kebijakan dan strategi dinas tersebut.

\section{Metodologi}

Penelitian ini merupakan penelitian deskriptif kualitatif yang menganalisis data dengan memberikan penjabaran deskripsi pada data secara sistematis dan faktual untuk memberikan uraian yang dapat menggambarkan kondisi di lapangan secara holistik serta memberikan solusi dari masalah secara akurat pada sebuah populasi atau daerah tertentu (Rianse, 2009: 30). Penelitian dilakukan pada instansi Dinas Kesehatan Kabupaten Bondowoso. Penggalian data pada responden dan informan menggunakan teknik purposive sampling, yaitu responden ditentukan secara sengaja oleh peneliti dengan memperhatikan pertimbangan tertentu (Sugiyono, 2010) dengan menggunakan metode kuesioner dan wawancara. Responden pada penelitian ini dibagi menjadi dua yaitu responden pelanggan yang merupakan masyarakat pengguna jasa pengajuan Surat Pelayanan Miskin (SPM) dan Laboratorium Kesehatan Daerah, serta responden karyawan (PNS atau non PNS) pada Dinas Kesehatan Kabupaten Bondowoso. Pada metode wawancara penentuan informan dilakukan dengan teknik snowballing sampling. Jumlah informan internal pada penelitian ini adalah 9 informan, yaitu Kepala Dinas, Subbag Keuangan, Subbag Perencanaan, Subbag Umum, staff dan pelanggan.

Analisis data menggunakan analisis data deskriptif yaitu dengan menyajikan data yang diperoleh dari hasil kuesioner dalam bentuk tabel, diagram atau grafik, dan analisis data kualitatif dengan metode analisis Interaktif Miles dan Hubberman. Datadata yang akan ditampilkan dalam bentuk analisis deskriptif meliputi data yang diperoleh dari metode BSC yang terdiri dari empat pendekatan, yaitu 1) perspektif pelanggan terdiri dari Tangibility, Reliability, Responsiveness, Assurance, dan Emphaty, 2) perspektif keuangan terdiri ekonomis, efisiensi dan efektifitas, 3) perspektif proses bisnis internal terdiri dari dimensi fasilitas, dimensi sumberdaya, dimensi proses, dan 4) perspektif pertumbuhan dan pembelajaran terdiri dari dimensi kemampuan dan dimensi motivasi. 
Skala pengukuran pada ketiga perspektif (perspektif pelanggan, proses bisnis internal dan pertumbuhan dan pembelajaran) menggunakan skala likert. Nilai skor rata-rata ini akan dibandingkan dengan nilai total rata-rata skor persepsi dan nilai total rata-rata skor harapan. Dari kedua nilai skor tersebut akan diperoleh selisih/gap yang disebut sebagai nilai skor servqual.

\section{Hasil dan Pembahasan}

\section{Perspektif Keuangan}

Pada Perspektif keuangan, analisis dilakukan untuk mengukur kinerja keuangan dengan cara menganalisis tingkat penyerapan anggaran, yang ditunjukkan dengan cara melihat hasil perbandingan target anggaran dengan realisasi penyerapan anggaran hingga akhir tahun anggaran. Kinerja keuangan dalam penelitian ini akan diukur menggunakan value for money dengan menganalisis efisiensi dan efektifitas anggaran sebagai berikut:

a. Ekonomis

Terdapat selisih antara pagu anggaran dengan realisasinya yaitu sebesar $\mathrm{Rp}$ 8.402.851.468,84. Angka tersebut bersal dari selisih anggaran Dinas Kesehatan Bondowoso pada tahun 2016 adalah sebesar Rp 69.781.774.452,- dengan realisasi hingga akhir masa anggaran adalah sebesar Rp 61.378.922.983,16. Nilai selisih tersebut disebabkan karena adanya realisasi pelaksanaan program kegiatan yang tidak sesuai dengan target yang diharapkan, sehingga dapat dikatakan bahwa nilai ekonomis pada persepektif keuangan Dinas Kesehatan Kabupaten Bondowoso sebesar $87,96 \%$ saja. Kinerja keuangan dapat dikatakan ekonomis apabila jumlah total anggaran yang disediakan dapat diserap keseluruhan hingga akhir masa anggaran. Hal ini, menunjukkan bahwa penyusunan perencanaan anggaran tepat dan sesuai kebutuhan. Pelaksanaan kegiatan pada Dinas Kesehatan Bondowoso belum dapat disebut ekonomis karena masih terdapat sisa anggaran yang tidak di serap pada akhir tahun anggaran.

Mardiasmo (2009) mengungkapkan bahwa nilai ekonomi suatu anggaran merupakan perbandingan antara input dengan input value. Input adalah target anggaran sedangkan input value adalah realisasi anggaran. Tingkat ekonomis penyerapan anggaran dapat dikatakan ekonomis apabila dengan tingkat realisasi tersebut dihasilkan output yang sesuai dengan output yang diinginkan pada saat perencanaan anggaran. 


\section{b. Efisiensi}

Value for money berikutnya akan diukur adalah tingkat efisiensi. Tingkat efisiensi diukur dengan cara membandingkan total target anggaran belanja langsung dengan total realisasi anggaran belanja. Mardiasmo (2009) menyampaikan bahwa tingkat efisiensi penyerapan anggaran berkaitan dengan konsep produktifitas dari anggaran itu sendiri. Berdasarkan Keputusan Menteri Dalam Negeri Nomor 690.900327 tahun 1996 tentang kriteria tingkat efisiensi anggaran belanja, maka penyerapan anggaran di Dinas Kesehatan Bondowoso dikategorikan cukup efisien karena hasil penghitungan nilai efisiensi antara $80 \%-90 \%$.

\section{c. Efektivitas}

Tingkat efektivitas dihitung dengan cara membandingkan realisasi pendapatan dengan target pendapatan yang ditetapkan. Mardiasmo (2009) menunjukkan bahwa efektivitas sangat berkaitan dengan penggunaan anggaran dalam mencapai sebuah target atau tujuan kebijakan. Tingkat efektivitas diukur dengan cara membandingkan realisasi penerimaan PAD dengan target penerimaan PAD. Hasil capaian kinerja pendapatan Dinas Kesehatan Bondowoso pada tahun 2016 adalah $\mathrm{Rp}$ 43.237.942.133,- dari target pendapatan sebesar $\mathrm{Rp}$ 49.057.681.182,-. Dari hasil capaian kinerja tersebut maka dapat dihitung tingkat efektivitasnya adalah $88,14 \%$, dan termasuk dalam kategori cukup efektif.

\section{Perspektif Pelanggan}

Pada perspektif pelanggan, terdapat lima dimensi yang diamati yaitu dimensi bukti fisik (tangible), dimensi kehandalan (reliability), dimensi daya tanggap (responsiveness), dimensi jaminan (assurance) dan dimensi perhatian (emphaty). Berikut akan disajikan nilai skor servqual dari kelima dimensi pada perspektif pelanggan, yaitu:

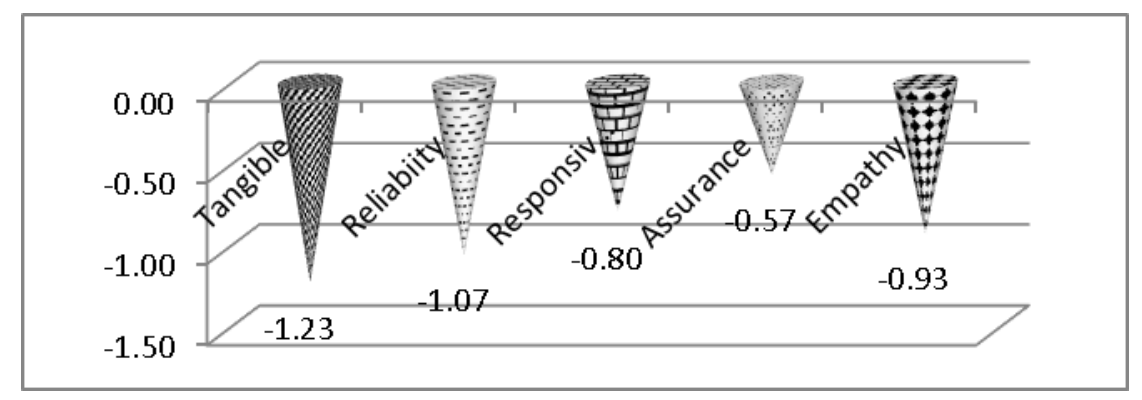

Gambar 1: Skor Servqual Perspektif Pelanggan

Gambar 1. menunjukkan bahwa nilai skor servqual menghasilkan perhitungan yang negatif. Nilai negatif berarti bahwa kualitas pelayanan yang dirasakan masih 
dirasa kurang bila dibandingkan dengan yang diharapkan. Dengan demikian tingkat kualitas pelayanan dapat dikatakan tidak baik atau tidak memuaskan (poor). Terdapat selisih (gap) pada hasil analisis skor servqual antara nilai skor persepsi dan skor harapan yang menunjukkan adanya perbedaan antara kualitas pelayanan yang diberikan dengan kualitas pelayanan yang diharapkan oleh masyarakat.

Jika dilihat antar dimensi pada perspektif pelanggan tersebut, maka dapat dilihat bahwa tingkat ketidakpuasan responden pelanggan pada perspektif ini paling tinggi adalah dimensi tangible (fisik) dengan nilai servqual-1,23. Nilai ini lebih rendah dari nilai servqual pada dimensi yang lainnya.

Perspektif Bisnis Internal

Perspektif proses bisnis internal terdapat tiga dimensi yaitu dimensi fasilitas,ndimensi sumber daya manusia, dan dimensi dimensi pengukuran. Perspektif proses bisnis internal digunakan untuk memberikan gambaran kinerja untuk mendukung pelaksanaan program dan kegiatan, yang meliputi sarana prasarana kantor, ketersediaan SDM serta tata cara proses pelaksanaan kegiatan dalam mencapai visi misi organisasi.

a. Dimensi Fasilitas

Dimensi fasilitas merupakan pengukuran kinerja dari sarana dan prasarana yang tersedia untuk melaksanakan program dan kegiatan. Dimensi fasilitas pada Dinas Kesehatan Kabupaten Bondowoso mencakup peralatan kerja seperti komputer, printer, fasilitas internet, kendaraan operasional dan sarana penunjang lainnya yang tersedia dalam jumlah yang cukup dan dalam kondisi baik dan layak pakai yang hasilnya akan disajikan pada gambar berikut.

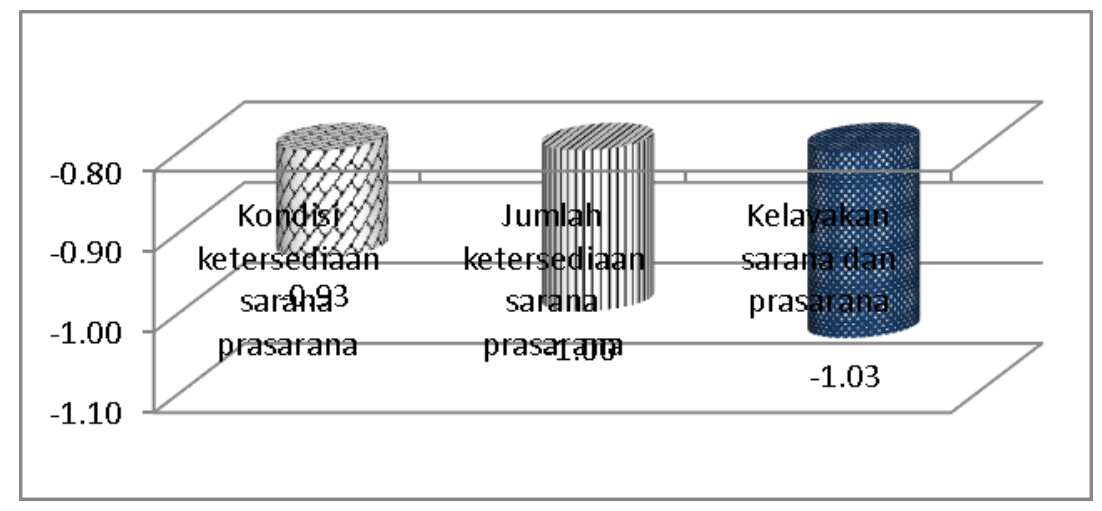

Gambar 2: Skor Servqual Dimensi Fasilitas Perspektif Bisnis Internal

Hasil analisis skor servqual tersebut diperoleh dengan menghitung selisih (gap) antara nilai skor persepsi dan skor harapan. Rujukan data pada Gambar 2. menunjukkan bahwa nilai skor servqual menghasilkan perhitungan yang negatif yaitu 
$(-1,03)-(-0,93)$. Nilai negatif pada skor servqual menunjukkan bahwa kualitas pelayanan yang dirasakan masih kurang apabila dibandingkan dengan yang diharapkan. Dengan demikian tingkat kualitas pelayanan dapat dikatakan tidak baik atau tidak memuaskan (Poor).

b. Dimensi Sumberdaya Manusia

Dimensi sumberdaya manusia merupakan pengukuran kinerja pada perspektif proses bisnis internal yang mencakup ketersediaan SDM yang dimiliki oleh instansi yang terkait jumlah dan spesialisasinya. Hal ini meliputi ketersediaan pegawai yang tepat jumlah serta memiliki kualifikasi dan latar pendidikan yang mendukung pelaksanaan program dan kegiatan Dinas Kesehatan Kabupaten Bondowoso. Gambar berikut akan menyajikan nilai skor servqual dari dimensi sumberdaya pada perspektif bisnis internal.

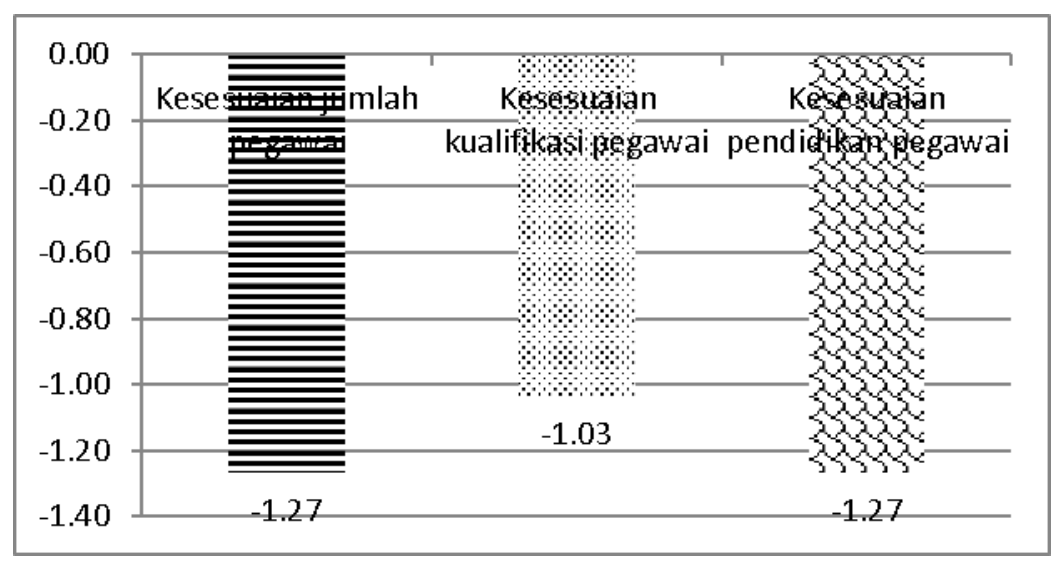

Gambar 3: Skor Servqual Dimensi Sumberdaya Manusia Perspektif Bisnis Internal

Data yang di tunjukkan pada Gambar 3 terdapat gap antara nilai skor persepsi dan harapan yang ditunjukkan dengan nilai skor servqual yang negatif. Nilai negatif pada skor servqual menunjukkan bahwa tingkat kualitas pelayanan yang dirasakan masih kurang apabila dibandingkan dengan yang diharapkan. Dengan demikian tingkat kualitas pelayanan dapat dikatakan tidak baik atau tidak memuaskan (poor).

c. Dimensi Proses

Dimensi proses merupakan pengukuran kinerja untuk mendapatkan gambaran tentang kesesuaian pelaksanaan program dan kegiatan terkait kesesuaian antara perencanaan dan pencapaiannya. Dimensi proses pada Dinas Kesehatan Kabupaten Bondowoso meliputi kesesuaian jadwal pelaksanaan program kegiatan sesuai dengan yang terdapat di rencana kerja, kemampuan pegawai dalam mengatasi hambatan pada pekerjaannya, pegawai mampu memberikan pelayanan sesuai dengan ketentuan standar pelayanan minimum (SPM). 
Hasil analisis nilai skor servqual yang memberikan gambaran bahwa pada dimensi proses, responden memiliki harapan yang lebih tinggi dibandingkan dengan pelayanan yang diberikan. Hasil analisis tersebut disajikan pada Gambar 4 di bawah ini.

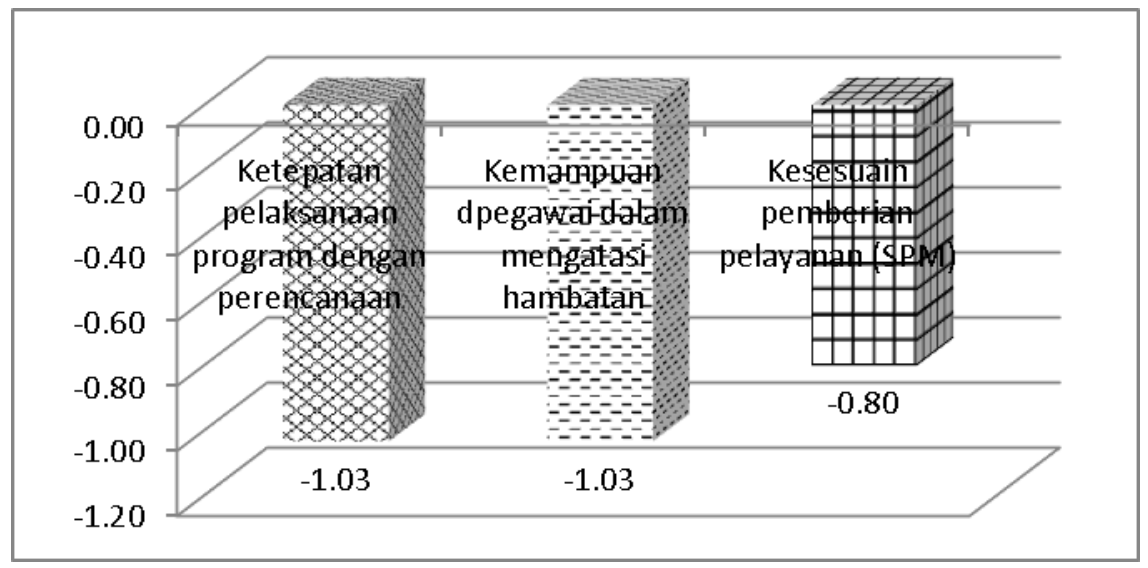

Gambar 4: Skor Servqual Dimensi Proses Perspektif Bisnis Internal

\section{Perspektif Pertumbuhan dan Pembelajaran}

Perspektif pertumbuhan dan pembelajaran terdapat dua dimensi pengukuran yaitu dimensi kemampuan dan dimensi motivasi.

\section{a. Dimensi Kemampuan}

Dimensi kemampuan merupakan pengukuran kualitas kinerja yang meliputi tingkat kepuasan pegawai terhadap kebijakan instansi terkait upaya meningkatkan pengetahuan dan kemampuan pegawai guna mendukung peningkatan kinerja organisasi. Beberapa hal yang tercakup dalam pengukuran dimensi kemampuan antara lain pemberian kesempatan kepada pegawai untuk melanjutkan pendidikan kejenjang yang lebih tinggi, pemberian kesempatan mengikuti diklat bagi peningkatan kapasitas dan kompetensi pegawai, menciptakan lingkungan kerja yang nyaman dan kondusif serta pemberian motivasi dan arahan dari pimpinan kepada pegawai dalam melaksanakan tugas.

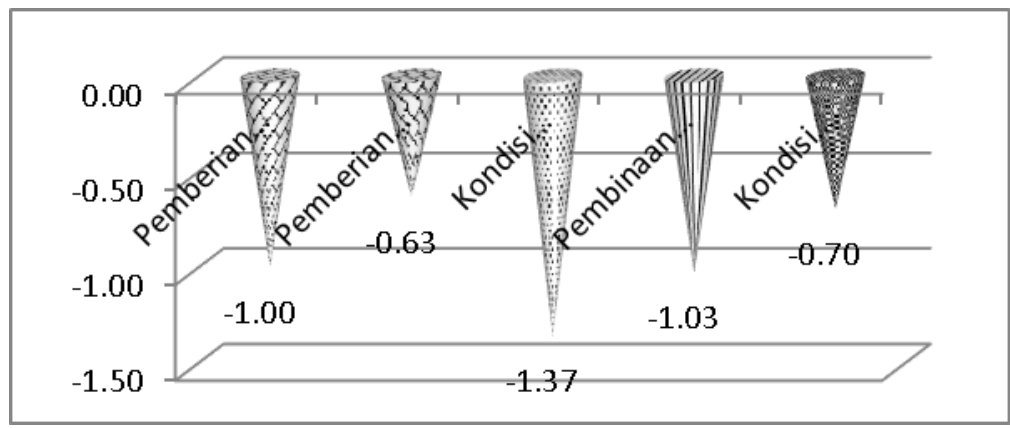

Gambar 5: Skor Servqual Dimensi Kemampuan 
Gambar 5 merupakan nilai skor servqual terhadap dimensi kemampuan. Berdasarkan data pada Gambar 5 menunjukkan bahwa nilai skor servqual menghasilkan perhitungan yang negatif yaitu antara $-1,37$ s.d $-0,63$. Nilai negatif pada hasil analisis skor servqual memperlihatkan bahwa kualitas kebijakan pada dimensi kemampuan yang diterapkan masih dirasa kurang memanuhi harapan pegawai. Dengan demikian tingkat kualitas pelayanan dapat dikatakan tidak baik atau tidak memuaskan (poor).

\section{b. Dimensi Motivasi}

Dimensi motivasi pengukuran kualitas kinerja terkait tingkat kepuasan pegawai terhadap kebijakan instansi dalam meningkatkan motivasi pegawai dalam bekerja. Upaya peningkatan motivasi kinerja karyawan dapat dilihat kedisiplinan pegawai dalam absensi, menciptakan ruangan kerja yang mendukung bagi pengembangan ide dan inovasi, pemberian promosi yang sesuai dengan kemampuan, penerapan punishment bagi pegawai yang melakukan pelanggaran, pimpinan selalu memberikan motivasi kerja dan teladan yang baik, adanya apresiasi bagi pegawai yang berprestasi, kerjasama dalam tim yang berjalan baik serta adanya komunikasi antar rekan kerja yang terjalin baik.

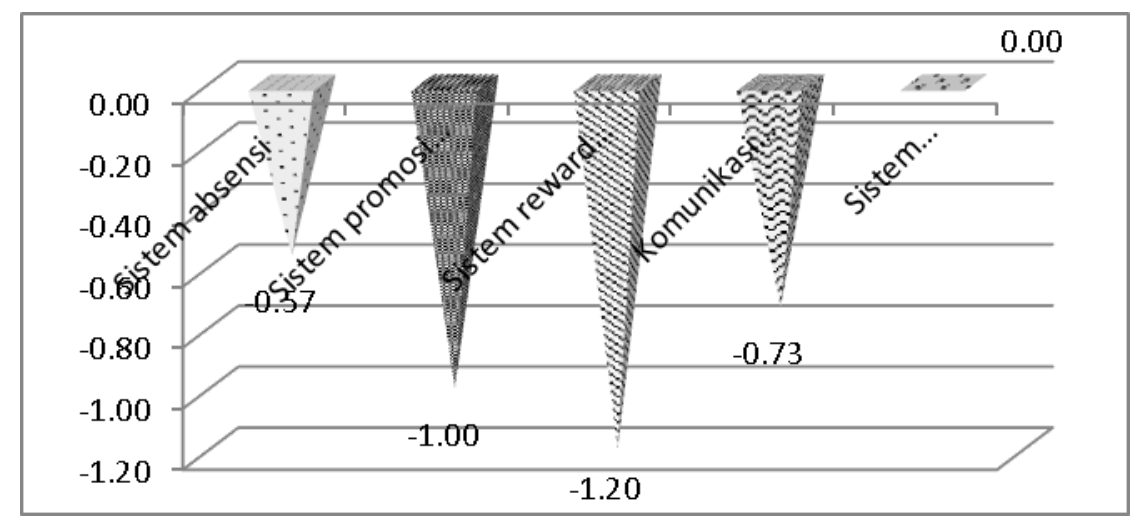

Gambar 6: Skor Servqual Dimensi Motivasi

Rujukan data pada Gambar 6 menunjukkan bahwa selisih antara nilai skor persepsi dan nilai skor harapan bernilai negatif. Nilai skor servqual negatif menunjukkan bahwa kualitas kebijakan pada dimensi motivasi yang diberikan masih dirasa kurang bila dibandingkan dengan yang diharapkan. Dengan demikian tingkat kualitas pelayanan dapat dikatakan tidak baik atau tidak memuaskan (poor).

Hasil analisis kinerja berdasarkan perhitungan Skor Servqual yang diselaraskan menggunakan metode pengambilan kesimpulan berdasarkan kriteria skala dan instrument pengukuran, maka diperoleh nilai kinerja BSC secara keseluruhan sebagai berikut: 
Tabel 1: Nilai Kinerja Akhir Balance Scoredcard

\begin{tabular}{|c|c|c|c|c|}
\hline No & Perspektif & $\begin{array}{c}\text { Dimensi } \\
\text { Pengukuran }\end{array}$ & $\begin{array}{c}\text { Nilai Skor } \\
(\%)\end{array}$ & Kategori \\
\hline \multirow{3}{*}{ I. } & \multirow{3}{*}{ Keuangan } & Ekonomis & 87,96 & Cukup Ekonomis \\
\hline & & Efisien & 87,96 & Cukup Efisien \\
\hline & & Efektif & 88,14 & Cukup Efektif \\
\hline \multirow{6}{*}{ II. } & \multirow{6}{*}{ Pelanggan } & Tangibile & 74,66 & Puas \\
\hline & & Reliability & 78,23 & Puas \\
\hline & & Responsiveness & 83,67 & Puas \\
\hline & & Assurance & 88,28 & Sangat Puas \\
\hline & & Emphaty & 80,69 & Puas \\
\hline & & Rata-rata & 81,10 & Puas \\
\hline \multirow{4}{*}{ III. } & \multirow{4}{*}{ Proses Bisnis Internal } & Fasilitas & 78,02 & Puas \\
\hline & & SDM & 72,70 & Puas \\
\hline & & Proses & 78,50 & Puas \\
\hline & & Rata-rata & 76,41 & Puas \\
\hline \multirow{3}{*}{ IV. } & \multirow{3}{*}{$\begin{array}{l}\text { Pertumbuhan dan } \\
\text { Pembelajaran }\end{array}$} & Kemampuan & 78,71 & Puas \\
\hline & & Motivasi & 83,90 & Puas \\
\hline & & Rata-rata & 81,30 & Puas \\
\hline
\end{tabular}

Sumber: Hasil Olah Data

Data Tabel 1. menunjukkan bahwa nilai kinerja Dinas Kesehatan Kabupaten Bondowoso dilihat dari berbagai perspektif yaitu:

1. Perspektif keuangan memiliki kinerja cukup ekonomis, cukup efektif namun cukup efisien

2. Perspektif pelanggan memiliki kualitas kinerja memuaskan

3. Perspektif proses bisnis internal memiliki kualitas kinerja memuaskan

4. Perspektif pertumbuhan dan pembelajaran memiliki kualitas kinerja memuaskan.

Hasil analisis terhadap kinerja Dinas Kesehatan Kabupaten Bondowoso dengan menggunakan balance scorecard dapat dikategorikan memuaskan. Namun demikian, kualitas pelayanan tersebut masih dapat ditingkatkan dengan berupaya melakukan perbaikan pada beberapa hal sebagaimana yang diinginkan oleh responden, sehingga harapan responden dapat terpenuhi.

Kesimpulan

Berdasarkan hasil analisis, kesimpulan kualitas kinerja Dinas Kesehatan Kabupaten Bondowoso dengan menggunakan metode balance scorecard, yaitu : (a) Perspektif keuangan memiliki kinerja cukup ekonomis (87,96\%), cukup efektif $(88,14 \%)$ dan cukup efisien (87,96\%). Pada perspektif keuangan tahun 2016 masih 
terdapat sisa penyerapan anggaran pada akhir tahun anggaran; (b) Perspektif pelanggan memiliki kualitas kinerja memuaskan $(81,10 \%)$. Dari hasil analisis menunjukkan bahwa harapan responden terhadap kualitas pelayanan Dinas Kesehatan Kabupaten Bondowoso masih belum terpenuhi, namun masih dapat dikatakan memuaskan; (c) Perspektif proses bisnis internal memiliki kualitas kinerja memuaskan (76,41\%). Pada perspektif ini, responden masih memiliki harapan agar kebijakan yang di buat oleh instansi mendukung pegawai untuk bekerja dengan baik; (d) Perspektif pertumbuhan dan pembelajaran memiliki kualitas kinerja memuaskan $(81,30 \%)$, Perspektif pertumbuhan dan pembelajaran dirasa cukup memuaskan dengan diberikannya kesempatan kepada pegawai untuk mengembangkan kemampuan dan meningkatkan pendidikannya.

\section{Saran}

Implikasi dari hasil penelitian ini dapat dijadikan sebagai rujukan bagi Dinas Kesehatan Kabupaten Bondowoso untuk meningkatkan kualitas pelayanan dan kinerjanya dengan mengakomodir kebutuhan masyarakat dan meningkatkan motivasi dan kemampuan pegawai dalam memberikan layanan dan kinerja terbaiknya. Beberapa saran untuk peningkatan kinerja pada Dinas Kesehatan Kabupaten Bondowoso, yaitu: (1) Diperlukan analisis yang lebih mendalam untuk menyesuaikan dengan kondisi di lapangan. Keberadaan UPTD Puskesmas membutuhkan penilaian kinerja tersendiri seperti halnya penerapan BSC; (2) Perlu adanya penyusunan rencana kegiatan dengan memperhatikan kondisi kebutuhan dan data di lapangan serta kemampuan pelaksanaan; (3) Sebaiknya analisis tingkat kebutuhan sumberdaya untuk meningkatkan kualitas kinerja dan pelayanan serta analisis dan evaluasi kinerja keuangan yang tidak hanya berbasis pada tingkat penyerapan anggaran, namun juga pada dampak dan manfaat kegiatan tehadap masyarakat atau sasaran perlu dilakukan 


\section{Daftar Referensi}

Kaplan, S. Robert. dan Norton, P. David. 2000. Menerapkan Strategi Menjadi Aksi Balance Scorecard. (alih bahasa: R Peter dan Pasla Yosi). Jakarta: Erlangga

Mardiasmo. 2009. Akuntansi Sektor Publik. Andi Offset. Yogyakarta

Mutaqien, Zainal. 2006. Penilaian Kinerja Lima Puskesmas Di Kota Cirebon Dengan Pendekatan Balanced Scorecard. Tesis Program Pasca Sarjana MPKP FEUI

Rianse, Usman. 2009. Metodologi Penelitian Sosial dan Ekonomi: Teori dan Aplikasi. Bandung: Alfabeta

Sharma, Ashu. 2009. Implementing Balance Scorecard for Performance Measurement. The Icfai University Journal of Business Strategy, Vol. VI, No. 1, 2009

Sugiyono, 2010. Statistika Untuk Penelitian. Bandung: ALFABETA

Utomo, Warsito. 2001. Kumpulan Tulisan dan Bahan Seminar, Yogyakarta: Penerbit Magister Administrasi Publik Universitas Gadjah Mada. 